\title{
Tumor Necrosis Factor-Related Apoptosis Inducing Ligand Stimulates Migration And Proliferation Of Vascular Smooth Muscle Cells
}

Madia Baizura Baharom ${ }^{1}$, Nor Saadah Md. Azahri ${ }^{2}$, Mohd. Ariffin Kaderi ${ }^{2}$ Suhana Mamat $^{2}$

${ }^{1}$ Department of Basic Medical Science, Kulliyyah of Medicine, International Islamic University Malaysia

${ }^{2}$ Department of Biomedical Science, Kulliyyah of Allied Health Sciences, International Islamic University Malaysia

Presenter: Madia Baizura Baharom

Introduction: Tumor Necrosis Factor-Related Apoptosis (TRAIL) has the ability to inhibit angiogenesis through programmed cell death, in the same time able to promote pro-angiogenic activity. It seems that TRAIL has an opposite effects make its role in ischemic disease and its function in a normal cell is still unclear. This study determines the effect of TRAIL in Vascular Smooth Muscle Cells (VSMCs). Materials and Methods: In this study, 6 wells in vitro Scratch Assay were conducted for migration and Celltiter $96 \AA$ Aqueous One Solution Cell Proliferation Assay (MTS) was performed for proliferation. In both assays, cells were serum arrested for 24, 48 and 72 hours, following stimulation with different concentration $(1 \mathrm{ng} / \mathrm{ml}, 20 \mathrm{ng} / \mathrm{ml}, 50 \mathrm{ng} / \mathrm{ml}$ and $100 \mathrm{ng} / \mathrm{ml})$ and different volume $(20 \mu \mathrm{L}$ and $100 \mu \mathrm{L})$ of TRAIL. PDGF-BB was used as positive control. Results of PDGFBB and TRAIL were compared with untreated VSMC. Results: It Is demonstrated that $100 \mu \mathrm{L}$ of $50 \mathrm{ng} / \mathrm{ml}$ TRAIL-induced VSMC shows significant $(p<0.05)$ higher migration rate percentage compared to untreated cells, included $100 \mu \mathrm{L}$ of $20 \mathrm{ng} / \mathrm{ml}$ PDGF-BB after 48 hours. However, in proliferation assay, the lowest concentration of TRAIL $(1 \mathrm{ng} / \mathrm{ml}, 20 \mu \mathrm{L})$ shows significantly higher proliferation rate compared to untreated cells after 24 hours $(p<0.05)$ meanwhile PDGF-BB $(1 \mathrm{ng} / \mathrm{ml}, 20 \mu \mathrm{L})$ indicates significant higher proliferation after 48 hours. Conclusion: This study demonstrates that TRAIL promotes the VSMC migration and proliferation in vitro. This indicates that migration and proliferation of VSMC upon vascular injury from media to intima not only involves PDGF-BB, but also TRAIL. Therefore, TRAIL contributes to intimal thickening that can lead to the obstruction of the blood vessels and it is a hallmark of atherosclerosis. 